\title{
Kadar Serat Tepung Buah Mangrove Sonneratia alba Asal Pesisir Wori Kabupaten Minahasa Utara
}

\author{
Suci Isbatul Janah ${ }^{1 *}$, Djuhria Wonggo ${ }^{1}$, Eunike L. Mongi ${ }^{1}$, Verly Dotulong ${ }^{1}$, Jenky Pongoh ${ }^{1}$, \\ Daisy M. Makapedua ${ }^{1}$, Grace Sanger ${ }^{1}$
}

\author{
1Program Studi Teknologi Hasil Perikanan \\ Fakultas Perikanan dan Ilmu Kelautan, Universitas Sam Ratulangi. \\ Jl. Kampus Unsrat Bahu, Manado 95115, Sulawesi Utara, Indonesia. \\ *Penulis Korespondensi: suciisbatu109@gmail.com \\ (Diterima 25-04-2020; Direvisi 19-05-2020; Dipublikasi 25-05-2020)
}

\begin{abstract}
ABSTRAK
Buah mangrove $S$. alba berpotensi sebagai sumber bahan pangan fungsional karena mengandung senyawa bioaktif yang baik untuk kesehatan. Selain sebagai pangan fungsional antioksidan, perlu juga digali potensi lain yang terkandung pada tepung buah $S$. alba seperti kandungan serat. Tujuan Penelitian ini adalah untuk mengetahui dan membandingkan kadar serat kasar dan serat pangan pada tepung buah $S$. alba muda (diameter buah $<3 \mathrm{~cm}$ ) dan buah tua (diameter buah $\geq 3 \mathrm{~cm}$ ) asal pesisir Wori kabupaten Minahasa Utara. Metode yang digunakan untuk analisis serat kasar adalah metode Apriyantono, et.al., (1989) dan untuk analisis serat pangan menggunakan metode AOAC (1995). Hasil analisa menunjukkan bahwa tepung buah $S$. alba muda asal pesisir Wori, Kabupaten Minahasa Utara memiliki kandungan serat kasar lebih tinggi yaitu 31,66\% jika dibandingkan dengan buah tua yaitu $28,66 \%$ dan hasil analisa serat pangan tepung buah $S$. alba muda juga lebih tinggi jika dibandingkan dengan tepung buah tua, buah muda memiliki kandungan serat pangan $43,32 \%$ dengan kandungan serat tidak larut air sebesar $38,66 \%$ dan serat larut air sebesar $4,66 \%$, sedangkan buah tua memiliki serat pangan 30,66\% dengan kandungan serat tidak larut air sebesar 25,33\% dan serat larut air sebesar 5,33\%.
\end{abstract}

Kata kunci: Sonneratia alba, serat kasar, serat pangan.

\section{PENDAHULUAN}

Mangrove merupakan satu tipe hutan tropis dan subtropis yang tumbuh di sekitar pantai atau muara sungai yang dipengaruhi oleh pasang surut dan banyak dijumpai di wilayah pesisir yang terlindung dari gelombang ombak (Kordi, 2012). Menurut Noor, et.al. (2006) mangrove memiliki peran penting dalam melindungi pantai dari gelombang, dan juga berperan sebagai tempat hidup berbagai jenis ikan. Selain itu mangrove juga dapat dimanfaatkan sebagai sumber bahan pangan, salah satunya yaitu buah mangrove Sonneratia alba yang dapat dijadikan tepung sebagai bahan baku untuk pembuatan kue seperti dodol dan waji (Santoso et.al., 2005). Buah S. alba bisa dikembangkan menjadi sumber bahan pangan karena sifatnya yang tidak beracun sehingga ketika sudah matang sudah dapat langsung dimanfaatkan menjadi jus atau bahan berbagai jenis kue (Baderan et.al., 2015). Purnobasuki, (2019) menyatakan bahwa secara tradisional di beberapa daerah seperti Sulawesi dan Maluku, tumbuhan mangrove sudah digunakan sebagai obat, minuman dan buah yang diolah menjadi tepung sebagai bahan baku untuk pembuatan berbagai macam kue. Buah Mangrove S. alba banyak digunakan sebagai obat karena mengandung senyawa bioaktif yang bermanfaat bagi kesehatan. Buah $S$. alba memiliki kandungan senyawa bioaktif antara lain, alkaloid, flavonoid, fenolik, tanin, saponin, steroid, dan terpenoid (Paputungan, et.al., 2017). Mangrove $S$. alba merupakan jenis mangrove yang banyak terdapat di pesisir Wori Kabupaten Minahasa Utara. Lahabu, et.al. (2015) menyatakan, daerah Wori, Minahasa Utara merupakan lokasi penting sebaran hutan mangrove jenis S. alba. Menurut Wonggo et.al. (2017), ekstrak methanol buah $S$. alba yang terdapat di desa Wori Sulawesi Utara mempunyai aktivitas antioksidan yang sangat kuat dengan IC50 $=3,5 \mathrm{ppm}$ dan mengandung senyawa bioaktif yaitu fenolik, flavonoid, steroid, triterpenoid, saponin, dan tannin sehingga buah $S$. alba berpotensi sebagai sumber bahan pangan fungsional. Selain sebagai pangan fungsional antioksidan, perlu juga digali potensi lain yang terkandung dalam tepung buah $S$. alba seperti serat.

Serat atau dietary fiber merupakan komponen dari jaringan tanaman yang tahan terhadap proses hidrolisis oleh enzim dalam lambung dan usus. Berdasarkan kelarutannya, serat pangan 
dibedakan menjadi serat larut (soluble dietary fiber) dan serat tidak larut (insoluble dietary fiber), tergantung kelarutan komponen serat tersebut di dalam air atau larutan buffer (Almatsier, 2001). Menurut American Association of Cereal Chemist (AACC) (2001), kurangnya mengkonsumsi makanan berserat dapat menyebabkan timbulnya penyakit degenerative, seperti konstipasi, meningkatnya resiko penyakit jantung koroner dan meningkatnya fluktuasi kadar insulin dan glukosa darah.

Ketahanan pangan menyangkut tentang ketersediaan pangan yang cukup untuk semua orang untuk keperluan hidup sehat. Ketahanan pangan menjadi hal yang sangat penting untuk dijaga karena merupakan isu pokok untuk pemenuhan kesejahteraan masyarakat dalam suatu negara (Nurhemi et.al., 2014). Menurut Hendriadi, (2019), perlu dilakukan suatu kebijakan untuk mempertahankan ketahanan pangan yang berkelanjutan salah satunya adalah dengan meningkatkan produksi pangan beragam, melalui pengembangan industri olahan pangan berbahan baku lokal, dan salah satu cara untuk mewujudkan kebijakan tersebut adalah dengan pemanfaatan tepung buah $S$. alba sebagai bahan pangan berbasis bahan baku lokal.

Berdasarkan uraian di atas, maka dirasa perlu dilakukan penelitian tentang kandungan serat dari tepung buah $S$. alba. Tujuan dari penelitian ini adalah untuk mengetahui apakah terdapat perbedaan kandungan serat kasar dan serat pangan pada tepung buah $S$. alba muda (diameter buah $<3 \mathrm{~cm}$ ) dan buah tua (diameter buah $\geq 3 \mathrm{~cm}$ ) yang diambil di sekitar pesisir Wori Kecamatan Wori Kabupaten Minahasa Utara Sulawesi Utara.

\section{METODE PENELITIAN}

\section{Bahan dan Alat}

Bahan baku yang digunakan adalah buah $S$. alba muda dan tua masing-masing sebanyak 1 $\mathrm{kg}$, diperoleh dari pesisir Wori kecamatan Wori Kabupaten Minahasa Utara Provinsi Sulawesi Utara. Bahan yang digunakan untuk analisis serat adalah buffer phospat (ph 7), enzim alpha amylase, akuades, asam klorida (HCL) $1 \mathrm{~N}$, enzim pepsin $1 \%$, enzim beta amylase, kertas saring, kertas lakmus, $\mathrm{H}_{2} \mathrm{SO}_{4}(1,25 \%), \mathrm{NaOH}(1,25 \%)$, ethanol (95\% dan 96\%) dan aceton.

Alat yang digunakan untuk mengukur diameter buah adalah jangka sorong, untuk pembuatan tepung yaitu pisau, blender, wadah plastik dan ayakan (60 Mesh). Sedangkan alat untuk analisis serat yaitu timbangan analitik, magnetik stirrer, thermometer, alumunium foil, gelas erlenmeyer, gelas piala, corong penyaring, gelas ukur, mikropipet, pengaduk gelas, cawan porselin, oven dan desikator.

\section{Analisa Serat Kasar (Apriyantono et.al., 1989)}

Sampel bebas lemak ditimbang sebanyak 1 gram, kemudian dimasukan ke dalam erlenmeyer dan ditambahkan $200 \mathrm{~mL} \mathrm{H}_{2} \mathrm{SO}_{4} 1,25 \%$, dipanaskan dalam magnetic stirrer suhu $100^{\circ} \mathrm{C}$ selama 30 menit sambil diaduk. Selanjutnya disaring dengan kertas saring kemudian dicuci dengan air panas sampai netral (diuji dengan kertas lakmus). Residu dipindahkan ke dalam erlenmayer, kemudian ditambahkan larutan $\mathrm{NaOH} 1,25 \%$ sebanyak $200 \mathrm{~mL}$ dan dipanaskan kembali suhu $100^{\circ} \mathrm{C}$ selama 30 menit sambil diaduk. Selanjutnya larutan didinginkan kemudian disaring dengan menggunakan kertas saring konstan yang sudah diketahui beratnya. Residu dicuci dengan menggunakan etanol $96 \%$ sebanyak $15 \mathrm{~mL}$, dilanjutkan dengan pencucian menggunakan air panas sampai netral (uji dengan kertas lakmus). Residu dalam kertas saring kemudian dioven pada suhu $100^{\circ} \mathrm{C}$ sampai berat konstan, kemudian dilakukan penimbangan. Selanjutnya, data hasil penimbangan dihitung dengan rumus:

$$
\% \text { kadar serat kasar }=\frac{(\text { Kertas Saring }+ \text { Ebdapan })-(\text { Kertas Saring })}{\text { Berat Sampel }} \times 100
$$

\section{Analisa Serat Pangan (AOAC, 1995)}

Sample ditimbang sebanyak 0,5 gram kemudian dimasukan ke dalam gelas erlenmeyer, ditambahkan buffer phospat sebanyak $50 \mathrm{~mL}$ dan $0,1 \mathrm{~mL}$ enzim alpha amilase kemudian dipanaskan di atas magnetic stirrer dengan suhu $100^{\circ} \mathrm{C}$ selama 30 menit sambil diaduk sesekali. Sampel diangkat dan didinginkan lalu ditambahkan $20 \mathrm{~mL}$ akuades dan ditambahkan $5 \mathrm{~mL} \mathrm{HCL}$ $1 \mathrm{~N}$ dan enzim pepsin $1 \%$ sebanyak $1 \mathrm{~mL}$ kemudian dipanaskan hingga suhu $100^{\circ} \mathrm{C}$ kembali selama 30 menit. Selanjutnya, erlenmeyer diangkat kemudian ditambahkan $5 \mathrm{~mL} \mathrm{NaOH} 1 \mathrm{~N}$ dan $0,1 \mathrm{~mL}$ 
enzim beta amilase. Gelas erlenmeyer ditutup dan dipanaskan hingga suhu $100^{\circ} \mathrm{C}$ selama 1 jam. Setelah itu didinginkan, kemudian disaring menggunakan kertas saring konstan yang sudah diketahui beratnya. Residu dicuci dengan ethanol $10 \mathrm{~mL}$ (2 kali) dan $10 \mathrm{~mL}$ aceton (2 kali). Sample lalu dikeringkan dengan oven pada suhu $105^{\circ} \mathrm{C}$ selama 1 malam, didinginkan pada desikator lalu ditimbang berat akhir (Serat Pangan Tak Larut). Filtrat yang dihasilkan dijadikan $100 \mathrm{~mL}$ dan ditambahkan $400 \mathrm{~mL}$ ethanol 95\%. Filtrat dibiarkan mengendap selama 1 jam. Selanjutnya filtrat disaring dengan kertas saring lalu dicuci dengan ethanol $10 \mathrm{~mL}$ (2 kali) dan 10 $\mathrm{mL}$ aceton $(2 \mathrm{kali})$ lalu dikeringkan semalam pada oven suhu $105^{\circ} \mathrm{C}$. Setelah itu, dimasukan ke dalam desikator dan ditimbang berat akhir (Serat Pangan Terlarut). Penghitungan serat pangan total bedasarkan rumus:

$$
\text { Serat Pangan Total }=\text { Serat Tak Larut }+ \text { Serat Terlarut }
$$

\section{HASIL DAN PEMBAHASAN}

\section{Serat Kasar}

Hasil analisa serat kasar, pada tepung buah S. alba muda dan tua dapat dilihat pada Tabel 1.

Tabel 1. Hasil analisa serat kasar tepung buah mangrove Sonneratia alba.

\begin{tabular}{cc}
\hline Sampel & Kadar Serat Kasar (\%) \\
\hline Tepung buah mangrove $S$. alba muda & 31,66 \\
Tepung buah mangrove $S$. alba tua & 28,66 \\
\hline
\end{tabular}

Tabel 1 menunjukkan bahwa kadar serat kasar tepung buah $S$. alba muda lebih tinggi dibandingkan dengan buah tua. Tepung buah S. alba muda memiliki kadar serat kasar 31,66\% sedangkan buah tua $28,66 \%$. Sedangkan perbandingan kadar serat kasar tepung $S$. alba dengan beberapa bahan pangan dapat dilihat pada Gambar 1 .

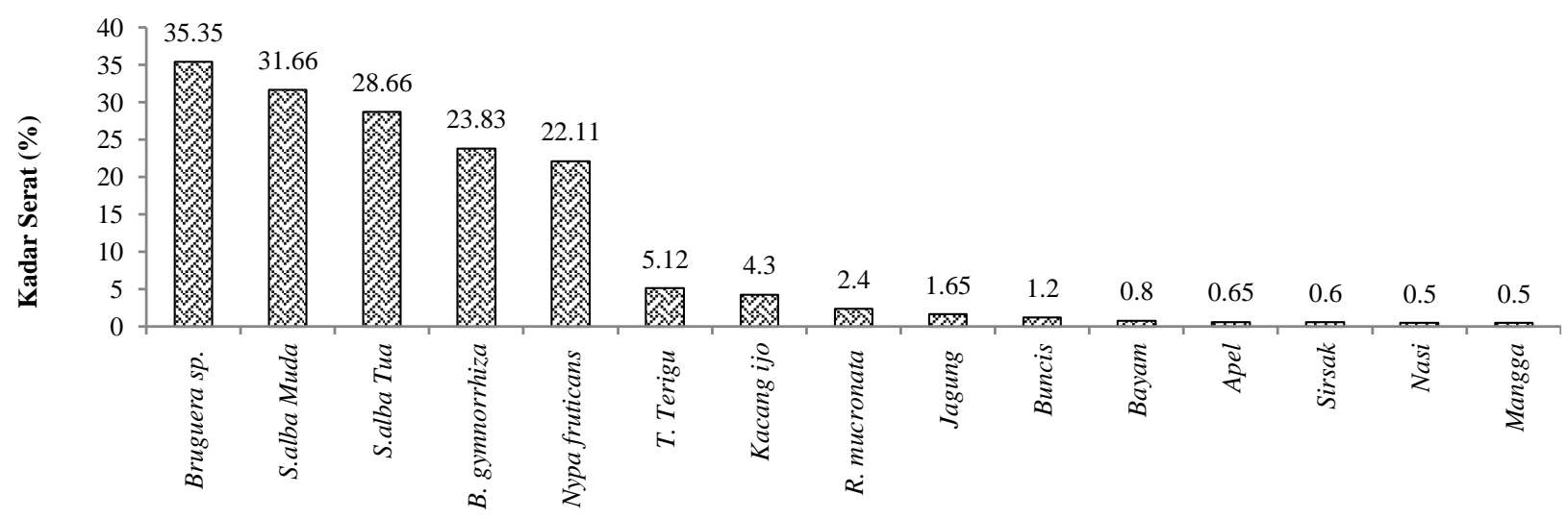

Gambar 1.Perbandingan kadar serat kasar buah mangrove Sonneratia alba dengan beberapa sumber bahan pangan lain.

Gambar 1. menunjukan bahwa kadar serat buah $S$. alba lebih rendah jika dibandingkan dengan tepung buah mangrove jenis Tancang (Bruguera sp.) yaitu 35,35\% (A'in et.al., 2016). Tetapi kadar serat kasar pada buah $S$. alba lebih tinggi jika dibandingkan dengan tepung buah Lindur (Bruguera gymnorrhiza) yaitu 23,83\% (Ernawati dan Nugroho, 2017), tepung buah Nipah (Nypa fruticans ) 22,11\% (Heriyanto et.al., 2011), tepung buah Rizhopora mucronata muda 2,40\% (Sulistiyati, 2015), juga lebih tinggi jika dibandingkan dengan bahan pangan lain seperti tepung terigu 5,12\% (Utama, et.al., 2019) nasi $0,5 \%$, jagung $1,65 \%$, kacang ijo 4,3\%, bayam $0,8 \%$, buncis $1,2 \%$, apel $0,65 \%$, sirsak $0,6 \%$ dan mangga $0,5 \%$ (Indonesia P.A.G, RSCM 1982).

Perbedaan kandungan serat pada beberapa jenis mangrove disebabkan karena perbedaan spesies dan karakteristik mangrove dari setiap hutan mangrove yang dipengaruhi oleh faktor-faktor seperti cuaca, bentuk lahan pesisir, jarak antara pasang surut air laut, ketersediaan air, oksigen dan tipe tanah (LPP Mangrove, 2006). Serat kasar yang bersumber dari sayuran dan buah-buahan diketahui sebagai zat non gizi namun diperlukan oleh tubuh untuk memperlancar pengeluaran feses (Tapotubun, 2018). Menurut Marsono, (2004), beberapa penyakit saluran pencernaan misalnya 
konstipasi, divertikulosis, hemoroid dan kanker kolon, berkaitan erat dengan asupan serat. Di dalam saluran pencernaan, sifat feses yang kaya serat menyebabkan pengenceran isi kolon, mempercepat transit sehingga mengurangi aksi karsinogenik dan mengurangi substrat untuk produksi karsinogen oleh bakteri.

\section{Serat Pangan}

Hasil analisa serat pangan, serat larut air dan serat tidak larut air pada tepung buah S. alba muda dan tua dapat dilihat pada Tabel 2.

Tabel 2. Hasil analisa serat pangan, serat larut air dan serat tidak larut air pada tepung buah mangrove Sonneratia alba.

\begin{tabular}{lccc}
\hline \multicolumn{1}{c}{ Sampel } & Serat Total (\%) & Serat tak larut (\%) & Serat larut (\%) \\
\hline Tepung buah mangrove $S$. alba muda & 43,32 & 38,66 & 4,66 \\
Tepung buah mangrove $S$. alba tua & 30,66 & 25,33 & 5,33 \\
\hline
\end{tabular}

Hasil analisis pada Tabel 2 menunjukkan bahwa tepung $S$. alba muda memiliki kadar serat pangan lebih tinggi yaitu $43,32 \%$ dibanding dengan buah tua yaitu 30,66\%. Sedangkan perbandingan serat pangan buah $S$. alba dengan sumber bahan pangan lain dapat dilihat pada Gambar 2.

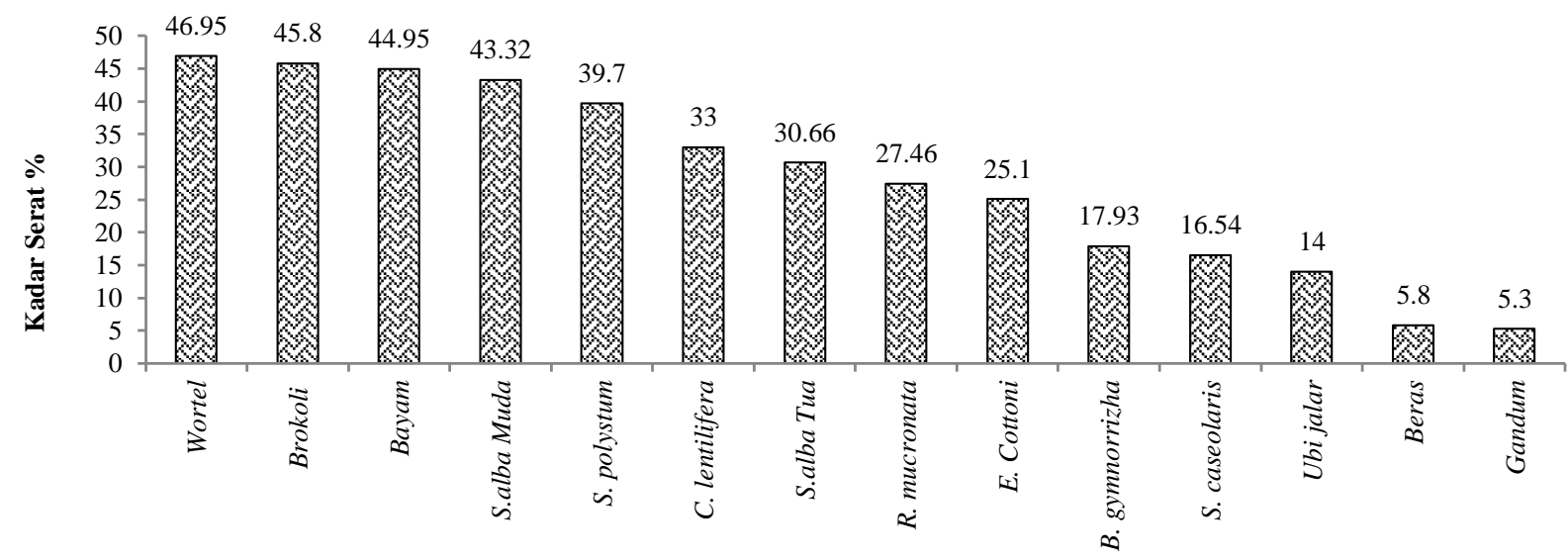

Gambar 2. Perbandingan kadar serat pangan buah mangrove Sonneratia alba dengan beberapa sumber bahan pangan lain.

Gambar 2 menunjukkan serat pangan pada tepung buah $S$. alba ini cukup tinggi jika dibandingkan dengan serat pangan pada buah mangrove lainnya seperti pada Sonneratia caseolaris 16,54\%, Rhizophora mucronata 27,46\% dan Bruguiera gymmorrhiza 17,93\% (Bunyapraphatsara et, al., 2003).Selain itu, serat pangan pada tepung buah $S$. alba muda juga lebih tinggi jika dibandingkan dengan beberapa jenis rumput laut yaitu $E$. cottonii dengan kadar serat pangan 25,1\%, Ulva fasciata 40\%, Caulerpa lentillifera 33\% dan Sargassum polycystum yaitu sebesar 39,7\% (Matanjun et,al., 2009). Tetapi kadar serat pangan pada tepung buah S. alba lebih rendah jika dibandingkan dengan beberapa sayuran seperti bayam 44,95\%, wortel 46,95\% dan brokoli yaitu 45,80\% (Muchtadi, 2001).

Masrul (2018), menyatakan konsumsi makanan tinggi serat bisa menjadi tindakan efektif untuk pencegahan kanker kolorektral (kanker usus besar) karena serat mampu membentuk cairan pelumas pada kolon sehingga mempercepat proses pengeluaran feses. Serat pangan juga mampu menurunkan kadar kolesterol dalam darah dan mencegah terjadinya peradangan dinding usus besar (Winarno, 2008). Menurut U.S. Department of Agriculture (2010) tingkat asupan dietary fiber yang direkomendasikan yaitu 34 g/hari untuk pria berusia19-30 tahun, $31 \mathrm{~g} / \mathrm{hari}$ untuk pria berusia 30-50 tahun, $28 \mathrm{~g} / \mathrm{hari}$ untuk wanita berusia 19-30 tahun, dan $22 \mathrm{~g} / \mathrm{hari}$ untuk wanita yang lebih tua dari 51 tahun.

Serat tidak larut merupakan serat yang tidak dapat larut dalam air, antara lain terdiri atas selulosa, hemiselulosa dan lignin, serat ini tidak membentuk gel ketika melewati usus halus dan sangat sulit difermentasi oleh mikroflora usus besar manusia (Fairudz, 2015). Hasil analisa serat tidak larut air pada Tabel 2 menunjukkan bahwa kadar serat tidak larut air pada tepung buah $S$. 
alba muda lebih tinggi jika dibandingkan dengan buah tua. Buah muda memiliki kadar serat tidak larut air sebesar $38,66 \%$ sedangkan pada buah tua yaitu $25,33 \%$. Kadar serat tidak larut pada tepung buah $S$. alba muda lebih tinggi jika dibandingkan dengan serat tidak larut air pada buah mangrove Rhizophora mucronata yaitu $26,93 \%$ dan pada buah Sonnerattia caseolaris 14,67\% (Bunyapraphatsara et, al., 2003). Kadar serat tidak larut air pada tepung buah S. alba muda juga lebih tinggi jika dibandingkan dengan beberapa rumput laut yaitu E. cottonii dengan kadar serat tidak larut air 6,8\%, dan Sargassum polycystum 34,1\% (Matanjun et,al. 2009) Namun serat tidak larut pada tepung buah $S$. alba muda lebih rendah jika dibandingkan dengan wortel 41,29\%, bayam 40,91\% dan brokoli 41,72\% (Muctadi, 2001). Perbandingan kadar serat tidak larut air dengan beberapa bahan pangan di atas dapat dilihat pada Gambar 3.

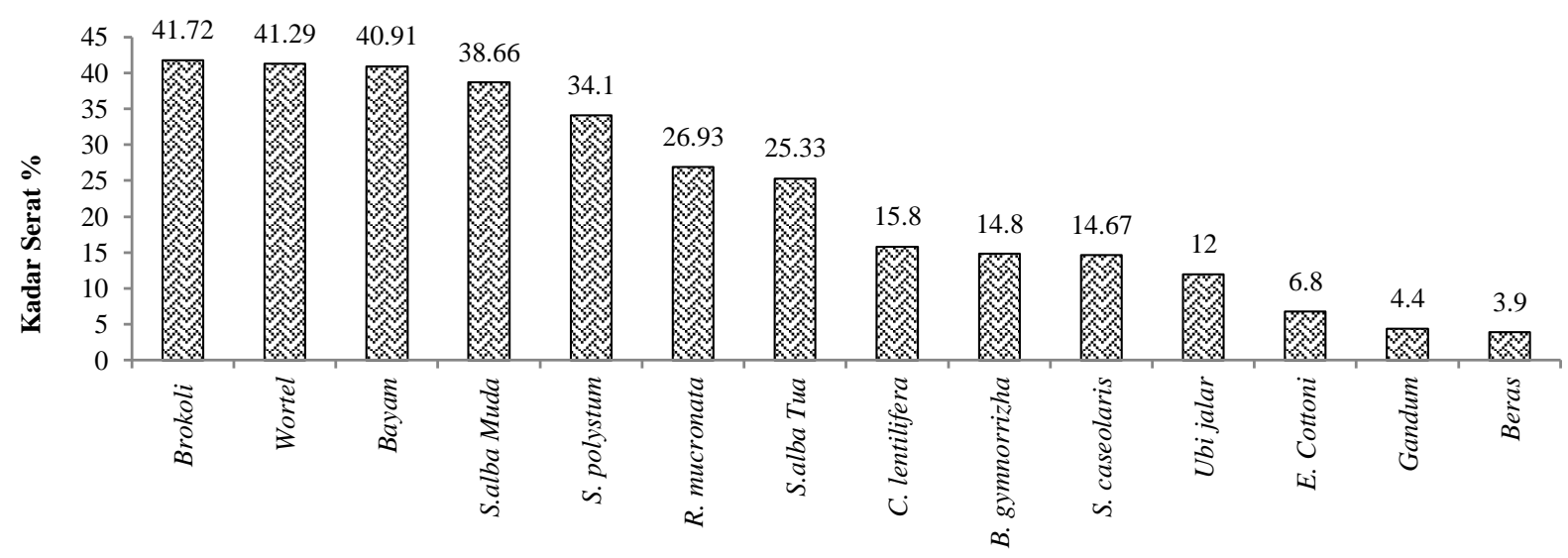

Gambar 3. Perbandingan kadar serat tidak larut air buah mangrove Sonneratia alba dengan beberapa sumber bahan pangan lain.

Menurut Sugiyanto et, al., (2017), terdapat hubungan antara asupan serat dengan kejadian konstipasi. Hal ini dibuktikan dengan hasil penelitiannya di Unit Rehabilitasi Sosial Puncak Gading, Semarang, yaitu konstipasi pada lansia terjadi pada responden yang memiliki asupan serat kurang. Penelitian tersebut menunjukkan sebanyak 62,5\% kejadian konstipasi terjadi pada responden yang memiliki asupan serat yang kurang, sedangkan pada responden yang memiliki asupan serat yang cukup kejadian konstipasi hanya terjadi sebanyak 21,1\%. Manfaat serat tidak larut untuk mencegah terjadinya konstipasi dan kanker kolon yaitu dengan cara mempersingkat waktu transit di dalam kolon dan menghasilkan feses lebih lunak dan lebih banyak sehingga dapat mempercepat proses pencernaan di dalam usus dan mencegah terjadinya konstipasi (Almatsier, 2001). Selain dapat mencegah konstipasti dan kanker kolon, serat tidak larut air juga mampu mengontrol berat badan atau kegemukan. Hal ini disebabkan karena makanan yang mengandung serat, akan tinggal dalam saluran pencernaan dalam waktu yang relatif singkat, sehingga terjadi penurunan proses penyerapan zat-zat gizi pada makanan, selain itu serat dapat memberi rasa kenyang yang lebih lama sehingga dapat menurunkan konsumsi makanan. Dengan berkurangnya konsumsi makanan dan penyerapan zat gizi, maka akan berpengaruh pada penurunan obesitas karena akumulasi lemak dalam tubuh akan berkurang (Muchtadi, 2001).

Serat larut adalah jenis serat yang dapat larut dalam air, sehingga dapat melewati usus halus dengan mudah dan difermentasi oleh mikroflora usus besar. Jenis-jenis serat larut antara lain pektin, gum, B-glukan dan fructan-Inulin (Nuralam, 2017). Pada Tabel 2 menunjukkan serat larut air pada buah $S$. alba tua lebih tinggi dibandingkan dengan buah muda. Buah tua memiliki kadar serat larut air sebesar 5,33\% sedangkan buah muda yaitu 4,66\%. Sedangkan perbandingan buah $S$. alba dengan sumber bahan pangan lain dapat dilihat pada Gambar 4. 


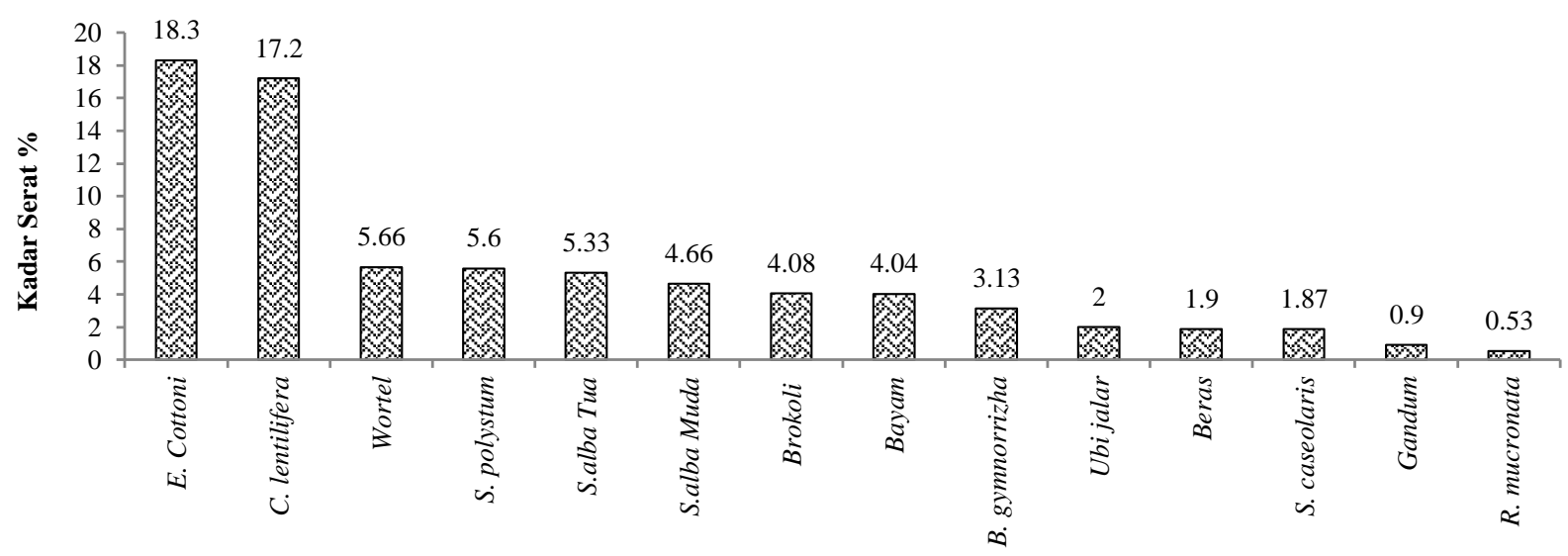

Gambar 4. Perbandingan kadar serat larut air buah mangrove Sonneratia alba dengan beberapa sumber bahan pangan lain.

Gambar 4 menunjukkan serat larut air pada tepung buah $S$. alba tua lebih tinggi jika dibandingkan dengan beberapa buah mangrove lain seperti Rhizophora mucronata $0.53 \%$ dan Bruguiera gymmorrrhiza 3,13\% (Bunyapraphatsara et, al., 2003). Tetapi kadar serta larut air pada tepung buah $S$. alba lebih rendah jika dibandingkan dengan rumput laut E. cottonii yaitu 18,3\%, Sargassum polycystum 5,6\%, Caulerpa lentillifera 17,2\% (Matanjun et,al. 2009), wortel 5,66\%, bayam 4,04\%, brokoli 4,08\% dan mentimun2,05\% (Muchtadi, 2001). Serat larut air sangat bermanfaat untuk kesehatan tubuh, diantaranya adalah dapat menurunkan kadar kolesterol dalam darah. Ramadhan (2011), menyatakan serat pangan (larut air), dapat menurunkan kadar kolesterol dalam darah. Dari hasil penelitiannya menunjukkan bahwa pemberian serat (nata de coco) pada tikus Sprague Dawley yang hiperkolesterol dengan dosis 3,53gr/200gr berat badan perhari selama dua minggu, mampu menurunkan kadar kolesterol sebesar 41,98\% dan mampu menurunkan kadar trigliserida sekitar 20,98\%. Penurunan kadar kolesterol dalam darah ini melibatkan asam empedu, sterol dan lemak, konsumsi serat yang tinggi dapat mengeluarkan lebih banyak asam empedu, juga lebih banyak sterol dan lemak yang dikeluarkan bersama feses. Konsumsi makanan tinggi serat dapat mencegah terjadinya penyerapan kembali asam empedu, kolesterol dan lemak, sehingga dapat menurunkan kadar kolesterol di dalam darah (Winarno, 2008). Serat larut air juga memiliki peran penting pada penurunan kadar gula dalam darah, sehingga dapat mencegah penyakit diabetes melitus. Dari hasil penelitian Amanina (2015), terdapat hubungan antara asupan serat dengan kejadian diabetes melitus tipe II yang terjadi di wilayah kerja Puskesmas Wonosari, Surakarta. Hal ini ditunjukan dengan data yang diperoleh yaitu dari total pasien yang menderita diabetes melitus tipe II, 67,5\% diantaranya adalah responden yang memiliki asupan serat tidak baik. Menurut Fairudz (2015), serat pangan mampu mereduksi penyerapan glukosa dan mampu mengurangi pemecahan glukosa oleh enzim. Serat juga mampu mengurangi daya cerna karbohidrat dan meningkatkan sensitivitas insulin sehingga dapat mengurangi kadar glukosa dalam darah, dan dapat mengarah pada pencegahan penyakit diabetes.

\section{KESIMPULAN}

Tepung buah mangrove Sonneratia alba muda asal pesisir Wori, Kabupaten Minahasa Utara memiliki kandungan serat kasar lebih tinggi yaitu 31,66\% jika dibandingkan dengan buah tua yaitu $28,66 \%$. Analisa kadar serat pangan juga menunjukkan tepung buah mangrove Sonneratia alba lebih tinggi dibandingkan dengan buah tua, buah muda memiliki kandungan serat pangan $43,32 \%$ dengan serat tidak larut air sebesar 38,66\% dan serat larut air sebesar 4,66\%, sedangkan buah tua memiliki serat pangan 30,66\% dengan serat tidak larut air sebesar 25,33\% dan serat larut air sebesar 5,33\%.Perlu dilakukan penelitian lebih lanjut untuk mengetahui jenis serat tidak larut air dan jenis serat larut air apa saja yang terdapat pada tepung buah mangrove S. alba asal pesisir Wori, Kabupaten Minahasa Utara. 


\section{DAFTAR PUSTAKA}

A'in, C., Suryanti, S., dan Sulardiono, B. (2018).Kandungan Gizi Pada Produk Olahan Mangrove (KruMang, BoMang, dan SiMang) Produksi Kelompok Tani "Ngudi Makaryo". INFO, 19(1), 24-33.

Amanina, A. (2015). Hubungan Asupan Karbohidrat dan Serat dengan Kejadian Diabetes Melitus Tipe II di Wilayah Kerja Puskesmas Purwosari (Doctoral dissertation, Universitas Muhammadiyah Surakarta).

Almatsier S. (2001). Prinsip Dasar Ilmu Gizi. Gramedia Pustaka Utama. Jakarta.

American Association of Cereal Chemist [AACC] (2001). The Definition of Dietary Fiber. AACC Report46(3), 112126.

Apriyantono, A., Fardiaz, D., Puspitasari, N. Sedarnawati, dan Budiyanto.(1989). Petunjuk Laboratorium Analisis Pangan. Bogor.

Assocation of Official Analytical and Chemistry (AOAC) (1995). Official Methods of Analysis. Penentuan Kadar Serat Pangan.

Baderan, D. W. K., Hamidun, M. S., Lamangandjo, C., dan Retnowati, Y. (2015). Diversifikasi Produk Olahan Buah Mangrove Sebagai Sumber Pangan Alternatif Masyarakat Pesisir Toroseaje, Kabupaten Pohuwato, Provinsi Gorontalo. Pros Semnas Masy Biodiv Indon, 1, 347-351.

Bunyapraphatsara, N., Jutiviboonsuk, A., Sornlek, P., Therathanathorn, W., Aksornkaew, S., Fong, H. H., ... \& Kosmeder, J. (2003). Pharmacological studies of plants in the mangrove forest.

Ernawati, E. dan Nugroho, M. (2017).Pengaruh Penambahan Tepung Mangrove Jenis Lindur (Bruquiera gymnorrhiza) Terhadap Karakteristik Nugget Ikan Lele Dumbo (Clarias gariepinus). AGRIKA: Jurnal Ilmu-Ilmu Pertanian, 11 (1).

Fairudz, A. (2015). Pengaruh serat pangan terhadap kadar kolesterol penderita overweight. Jurnal Majority, 4(8), 121-126.

Hendriadi, A. (2019). Ketahanan Pangan: Capaian dan Arah Kebijakan. Disampaikan pada Simposium Nasional Between Food Security and Safety: Mencari Konsep Baru. Badan Ketahanan Pangan. Jakarta.

Heriyanto, N.M., Subiandono, E. dan Karlina, E. (2011). Potensi dan Sebaran Nipah (Nypa fruticans (Thunb.)Wurmb) Sebagai Sumberdaya Pangan (Potency and distribution of Nypa palm (Nypafruticans (Thunb.)Wurmb) as food resource). Jurnal Penelitian Hutan dan Kon-servasi Alam, 8(4).

Indonesia, P.A.G. (1982) Bagian Gizi RSCM. Penuntun Diet.

Kordi, K.M.G.H. dan Ghufran, M. (2012). Ekosistem Mangrove Potensi, Fungsi, dan Pengelolaan. Rineka Cipta. Jakarta.

Lahabu, Y., Schaduw, J. N., dan Windarto, A. B. (2015).Kondisi Ekologi Mangrove Di Pulau Mantehage Kecamatan Wori Kabupaten Minahasa Utara Provinsi Sulawesi Utara. Jurnal Pesisir dan Laut Tropis, 3(2), 41-52.

LPP Mangrove (2006). Modul Pendidikan Lingkungan Mangrove. LPP Mangrove Publ. Bogor. 55 hlm.

Marsono,Y., 2004. Serat Pangan Dalam Perspektif Ilmu Gizi. Pidato Pengukuhan Jabatan Guru Besar. Fakultas Teknologi Pertanian. Gadjah Mada. Yogyakarta.

Masrul, M. (2018). Fibre Consumption Reduced Risk of Colorectal Cancer Patients in Western Countries: a MetaAnalysis. Jurnal Kesehatan Masyarakat Andalas, 12(2), 97-101.

Matanjun, P., Mohamed, S., Mustapha, N. M., and Muhammad, K. (2009). Nutrient Content of Tropical Edible Seaweeds, Eucheuma cottonii, Caulerpa lentillifera and Sargassum polycystum. Journal of Applied Physiology, 21(1), 75-80.

Muchtadi, D. (2001). Sayuran Sebagai Sumber Serat Pangan Untuk Mencegah Timbulnya Penyakit Degeneratif. Jurnal Teknologi dan Industri Pangan, 12(1), 61-71.

Noor, Y.R., Khazali, M., dan Suryadiputra, I.N.N. (2006). Panduan Pengenalan Mangrove di Indonesia. Bogor. Wetlands Internasional Indonesia Programme. Bogor.

Nuralam, A.S. (2017). Produksi Serat Pangan Larut dari Buah Belimbing Wuluh (Averrhoa bilimbi L.) dengan Menggunakan Berbagai Variasi Konsentrasi Asam Klorida. (Doctoral Dissertation, Universitas Islam Negeri Alauddin Makassar).

Nurhemi, S. R., Soekro, G. S. R., dan Suryani, R. (2014). Pemetaan Ketahanan Pangan di Indonesia: Pendekatan TFP dan Indeks Ketahanan Pangan. Bank Indonesia. WP/4, 1-70.

Paputungan, Z., Wonggo, D., dan Kaseger, B. E. (2017). Uji Fitokimia dan Aktivitas Antioksidan Buah Mangrove Sonneratia Alba Di Desa Nunuk Kecamatan Pinolosian Kabupaten Bolaang Mongondow Selatan Sulawesi Utara. Media Teknologi Hasil Perikanan, 5(3), 96-102.

Purnobasuki, H. (2019). Potensi mangrove sebagai tanaman obat. Biota: Jurnal Ilmiah Ilmu-Ilmu Hayati, 9(2).

Ramadhan, F.F. (2011). Pengaruh Pemberian Nata De Coco Terhadap Kadar Kolesterol Total dan Trigliserida Pada Tikus Hiperkolesterolemia. Semarang: Program Studi Ilmu Gizi Fakultas Kedokteran Universitas Diponegoro.

Santoso, N., Bayu, C. N., Ahmad, F. S., \& Ida, F. (2005). Resep makanan berbahan baku mangrove dan pemanfaatan nipah. Lembaga Pengkajian dan Pengembangan Mangrove. Jakarta, 70. 
Santoso, N., Nurcahya, B.D. dan Siregar, I.F. (2005). Resep Makanan Berbahan Baku Mangrove dan Pemanfaatan Nipah. Lembaga Pengkajian dan Pengembangan Mangrove. Jakarta.

Sugiyanto, V. R. P., Rahfiludin, M. Z., dan Suyatno, S. (2017). Hubungan Asupan Serat, Lemak, dan Posisi Buang Air Besar Dengan Kejadian Konstipasi Pada Lansi. Jurnal Kesehatan Masyarakat (e-Journal), 3(3), 257-265.

Sulistiyati, T.D. (2015). Antidiare Mangrove Crackers From Rhizophora Mucronata Fruit. Journal of Innovation and Applied Technology. 1(1), 82-87.

Tapotubun, A. M. (2018). Komposisi Kimia Rumput Laut (Caulerpa lentillifera) dari Perairan Kei Maluku dengan Metode Pengeringan Berbeda. Jurnal Pengolahan Hasil Perikanan Indonesia, 21(1), 13-23.

U.S. Department of Agriculture and U.S. Department of Health and Human Services (2010). Dietary Guidelines for Americans, 2010.7 $7^{\text {th }}$ Edition, U.S. Government Printing Office. Washington, DC.

Utama, IDGDA., Wisaniyasa, NW., Widarta IWR (2019). Pengaruh Perbandingan Tepung Terigu Dengan Tepung Kecambah Jagung (Zea mays L.) Terhadap Karakteristik Flakes. Jurnal Ilmu dan Teknologi Pangan. 8(2),140-149.

Winarno, F.G. (2008). Kimia Pangan dan Gizi Edisi Terbaru. M-Brio Press. Bogor.

Wonggo, D., Berhimpon, S., Kurnia. D., dan Dotulong, V. (2017). Antioxidant Activities of Mangrove Fruit (Sonneratia alba) taken From Wori Village, North Sulawesi, Indonesia. Int. J. ChemTechRes, 10, 284-290. 